\title{
MENINGKATKAN KEMAMPUAN MOTORIK HALUS ANAK MELALUI KEGIATAN MERONCE DENGAN MEDIA MANIK-MANIK DI KELOMPOK B TK AISYIYAH BUSTANUL ATHFAL BROMO MEDAN
}

\author{
Erna Kusnita
}

Surel : ernakusnita@gmail.com

\begin{abstract}
ABSTRAK
Penelitian ini bertujuan untuk meningkatkan motorik halus anak melalui kegiatan meronce dengan media manik-manik di kelas B TK Aisyiyah Bustanul Atfal Bromo Medan. Subjek dalam penelitian tindakan kelas ini adalah anak taman kanak-kanak kelas B yang berjumlah 15 orang. Teknik pengumpulan data yang digunakan dalam penelitian ini adalah dengan menggunakan data kuantitatif berupa test dan data kualitatif berupa observasi. Hasil observasi menunjukkan bahwa pada siklus I guru (peneliti) sudah dapat meningkatkan kemampuan motorik halus anak dengan kegiatan meronce dengan media manik-manik dalam kegiatan pembelajaran motorik halus dengan baik (43\%) dan pada siklus II guru (peneliti) dapat menerapkan meningkatkan kemampuan motorik halus dalam kegiatan meronce dengan media manik-manik dengan sangat baik (88\%).
\end{abstract}

Kata Kunci : Motorik Halus Anak, Meronce, Media Manik-Manik

\section{PENDAHULUAN}

Dunia anak merupakan dunia yang penuh dengan canda tawa dan kegembiraan dengan berbagai prilaku yang tidak dibuat buat sehingga orang dewasa akan ikut terhibur dengan hanya melihat tingkah polah mereka.

Dalam Undang-Undang Republik Indonesia Nomor 20 Tahun 2003 Pasal 28 menyatakan bahwa :

(1) Pendidikan anak usia dini diselenggarakan sebelum jenjang pendidikan dasar. (2) Pendidikan anak usia dini dapat diselenggarakan melalui jalur pendidikan formal, non formal, dan atau informal. (3) Pendidikan anak usia dini pada jalur pendidikan formal berbentuk Taman
Kanak-kanak (TK), Raudhatul Athfal (RA), atau bentuk lain yang sederajat. (4) Pendidikan anak usia dini pada jalur pendidikan non formal berbentuk Kelompok Bermain (KB), Taman Penitipan Anak (TPA), atau bentuk lain yang sederajat. (5) Pendidikan anak usia dini pada jalur pendidikan informal berbentuk pendidikan keluarga atau pendidikan yang diselenggarakan oleh lingkungan.

Selama pertumbuhannya, minat dan permainan anak selalu terkait dengan perkembangan kemampuannya. Namun setelah kaki, tangan, dan bagian badan yang lain sudah terkoordinasi dengan baik dan mantap sertbahasa sudah baik pula maka anak mulai merancang 

berbagai alternatif perbuatan yang lain sehingga kemampuannya menjadi sangat luas dan semakin kompleks.

Perkembangan fisik motorik memegang peranan yang sama penting dengan perkembangan kognitif dan sosial. Berkaitan dengan perkembangan fisik ini, Kuhlen dan Thomson dalam Aisyiyah (2013: 4.14) mengemukakan bahwa perkembangan fisik seorang anak manusia meliputi 4 aspek, yaitu :

a. Sistem saraf di otak yang mempengaruhi perkembangan kecerdasan dan emosi.

b. Otot-otot yang mempengaruhi perkembangan kekuatan dan perkembangan motorik.

c. Kelenjar endokrin yang menyebabkan munculnya polapola tingkah laku baru.

d. Struktur tubuh/fisik, meliputi tinggi, berat dan proporsi.

Menurut Gallahue dalam widia 2010 menyatakan bahwa "usia prasekolah merupakan waktu yang paling optimal untuk perkembangan motorik anak".

Seringkali orang dewasa baik itu guru maupun orang tua secara tidak sadar memaksa anak untuk belajar menulis indah tanpa memperhatikan pertumbuhan dan perkembangan anak yang harus dilaluinya terlebih dahulu sebelum anak mampu menulis dengan sempurna sesuai yang diharapkan. Walau ada anak yang mampu mengikuti kemauan orang dewasa tersebut, namun dapat menyebabkan kejenuhan yang membuat anak malas sekolah dan belajar ditahun tahun berikutnya.

Oleh karena itu penting bagi orang dewasa khususnya pendidik untuk tahu dan memahami tentang tahap perkembangan dan pertumbuhan anak usia dini serta menguasai strategi pembelajaran yang bervariatif untuk mengembangkan kemampuan anak khususnya kemampuan motorik halus anak melalui kegiatan bermain.

Agar kemampuan motorik halus anak usia dini dapat berkembang sebagaimana mestinya, maka perlu memadukan pembelajaran melalui bermain dengan program kegiatan belajar di Taman Kanak-kanak, salah satunya yaitu melalui kegiatan meronce dengan media manik-manik.

Di TK Aisyiyah Bustanul Athfal Bromo Medan kegiatan pembelajaran motorik halusnya terfokus pada kegiatan menulis saja di buku dan papan tulis seperti yang diterapkan pada anak usia SD sehingga terjadilah kegiatan pembelajaran yang membosankan.

Peneliti menyadari ada hal penting yang menjadi masalah di tempat peneliti mengajar pada kelompok B TK Aisyiyah Bustanul Athfal Bromo Medan yaitu anak didik peneliti sebagian besar belum mampu melaksanakan kegiatan meronce dengan media manikmanik. Hal ini dibuktikan dengan tidak memuaskannya hasil karya anak pada kegiatan pengembangan motorik halus. 
Dari pernyataan diatas, saya sebagai peneliti sekaligus pendidik di TK Aisyiyah Bustanul Athfal Bromo Medan mengidentifikasi masalah yang terjadi ditempat saya mengajar antara lain sebagai berikut:

a. Belum berkembangnya motorik halus anak dengan optimal.

b. Pada waktu kegiatan pembelajaran dilaksanakan anak bercerita dan bermain dengan temannya.

c. Hasil belajar anak belum sesuai dengan harapan guru yaitu anak mampu untuk meronce dengan benar.

d. Guru tidak menggunakan media yang ada dilingkungan sekolah sehingga anak tidak tertarik untuk melakukan kegiatan pembelajaran.

e. Kurangnya pengetahuan guru dan orangtua tentang tumbuh kembang anak.

f. Anak tidak mau mengerjakan tugasnya.

Berdasarkan uraian di atas, maka peneliti tertarik untuk melakukan penelitian tentang: "Meningkatkan Kemampuan Motorik Halus Anak Melalui Kegiatan Meronce Dengan Media Manik-Manik di Kelompok B TK Aisyiyah Bustanul Athfal Bromo Medan Tahun Pelajaran 2016/2017’.

Berdasarkan rumusan masalah yang telah dikemukakan di atas, maka tujuan yang ingin dicapai dalam penelitian ini adalah meningkatkan kemampuan Motorik halus anak melalui kegiatan meronce dengan media manik-manik di kelompok B TK Aisyiyah Bustanul Athfal Bromo Medan Tahun Pelajaran 2016/2017.

\section{METODE PENELITIAN}

Penelitian ini adalah penelitian Tindakan Kelas (classroom riset) yang dilakukan selama 2 siklus .Subjek penelitian adalah murid di kelompok B TK Aisyiyah Bustanul Athfal Bromo Medan yang berjumlah 15 orang, dengan anak laki-laki 6 orang dan anak perempuan 9 orang pada tahun pelajaran 2016/ 2017. Penelitian ini dilakukan di TK Aisyiyah Bustanul Athfal Bromo Medan yang berada di Jln. Bromo Gg. Silaturrahim no. 22 Medan. Penelitian ini dilaksanakan pada semester I tahun ajaran 2016/2017 yaitu dari bulan Agustus sampai bulan November 2016.

Sumber data dalam penelitian ini adalah daftar nilai hasil belajar pada tahap penjajagan (data awal), anak, peneliti, obsever dan kepala sekolah sebagai data pendukung, jenis data yang di dapat dari:
a. Proses belajar mengajar
b. Nilai test anak
c. Observasi selama pembelajar

Teknik yang digunakan untuk memeriksa validitas data antara lain adalah triangulasi. Triangulasi adalah teknik pemeriksaan validitas data dengan memanfaatkan sarana di luar data itu untuk keperluan pengecekan atau pembandingan data itu (Lexy Moelong dalam Sarwiji Suwandi, 2008 : 69). Validitas data yang digunakan antara lain dengan 
triangulasi sumber data dan triangulasi metode pengumpulan data. Dalam penelitian ini teknik triangulasi untuk mengetahui kesulitan yang dihadapi siswa dalam kemampuan motorik halus dan faktor penyebabnya. Untuk itu peneliti membandingkan data hasil penelitian dari berbagai metode antara lain dengan tes, observasi dan dokumentasi. Triangulasi data dilakukan dengan cara :

a. Cross checking, peneliti melakukan pengecekan (checking) antara hasil metode pengumpulan data yang diperoleh melalui tes, observasi dan dokumentasi dengan memadukan hasil ketiganya. Dalam hal ini bertujuan memperoleh informasi yang benar dan meyakinkan.

b. Cek ricek, yaitu pengulangan kembali data yang diperoleh melalui berbagai sumber data, waktu, maupun metode dan informasi serta tempat memperoleh data (setting).

Analisis data dilakukan melalui teknik pengumpulan data yaitu melalui observasi interpretasi dilakukan bersama dengan pelaksanaan tindakan perbaikan. Interpretasi dilakukan untuk menginterpretasikan data mengenai fenomena/ gejala yang diteliti. Observasi dilakukan berdasarkan 5 prinsip:
a. Guru
dan
merencanakan
kolaborator
bersama-sama

b. Guru dan kolaborator menetapkan fokus observasi

c. Guru dan kolaborator membangun kriteria observasi

d. Guru dan kolaborator memiliki keterampilan observasi

Balikan (feedback) diberikan berdasarkan data faktual yang direkam secara cermat dan sistematis. Pada kegiatan ini observasi yang digunakan adalah observasi terfokus yang secara khusus ditujukan untuk mengamati aspek-aspek tertentu selama kegiatan pembelajaran yang ditetapkan bersama guru dan kolaborator.

Analisis data dapat dilakukan secara bertahap, yaitu :

a. Pada tahap pertama data diseleksi, difokuskan jika perlu ada yang direduksi (reduksi data).

b. Data yang sudah terorganisasi dideskripsikan sehingga bermakna, baik dalam bentuk narasi, grafik maupun tabel.

c. Berdasarkan paparan atau deskripsi yang telah dibuat ditarik kesimpulan dalam bentuk pernyataan.

Data tes dianalisis dengan nilai rata-rata dan ketuntasan belajar dengan memakai rumus sebagai berikut:

Nilai akhir rata-rata yang di peroleh anak menggunakan rumus:

$$
\bar{x}=\frac{\sum X}{N}
$$

Keterangan :

$\bar{x}=$ Nilai Akhir Rata-rata anak 
$\Sigma \mathrm{X}=$ Jumlah Nilai akhir anak

$\mathrm{N}=$ Jumlah Siswa

(Suharsimi, 2002 :264)

Ketuntasan belajar secara klasikal dihitung dengan menggunakan rumus :

(Suharsimi, 1987)

Keterangan :

$$
P=\frac{n}{N} x 100 \%
$$

$\mathrm{P} \quad=$ Tingkat Kemampuan

$\mathrm{n} \quad$ = jumlah anak yang diperoleh dari data

$\mathrm{N} \quad=$ Jumlah anak

$100 \%=$ Nilai Konstan

Indikator kinerja keberhasilan penelitian adalah mengalami peningkatan hasil belajar dari sebelum melakukan kegiatan meronce dengan manik-manik dalam pengembangan motorik halus di kelompok B TK Aisyiah Bustanul Atfal Bromo Medan Tahun Pelajaran 2016/2017. Acuan dalam menentukan keberhasilan atau keefektifan penelitian adalah adanya peningkatan kemampuan motorik halus anak dalam meronce dengan menggunakan manik-manik memperoleh nilai lebih dari $70 \%$.

\section{HASIL PENELITIAN DAN PEMBAHASAN}

Data hasil penelitian yang diperoleh guru dan kolaborator melalui observasi dan hasil kerja anak selama proses kegiatan. Adapun deskripsi hasil data meliputi data tentang rencana, pelaksanaan pengamatan dan refleksi pada tindakan perbaikan siklus I adalah sebagai berikut :

Membuat rencana pelaksanaan :

a. Melaksanakan kegiatan meronce dengan manik-manik sesuai dengan tema yang diawali dengan kegiatan bernyanyi dan bercakap-cakap sesuai dengan tema pada hari itu. Agar anak terdorong untuk mengikuti kegiatan pembelajaran.

b. Mengelola kelas secara menyeluruh, yaitu menciptakan suasana kelas yang PAIKEM.

c. Menyiapkan media dan sumber belajar yang menarik.

d. Memberikan reward atas hasil karya anak sehingga dapat memotivasi anak untuk melakukan meronce denagn media manik-manik.

e. Guru membuat skenario perbaikan pembelajaran dan memeriksa kemungkinan keterlaksanaannya.

Langkah-langkah yang dilakukan guru pada proses pembelajaran adalah sebagai berikut :

a. Guru melakukan kegiatan pembukaan yang dapat menyenangkan anak

b. Guru memberikan gambaran tempat yang akan ditanyakan

c. Guru bertanya pada anak tempat dia tinggal

d. Guru menggunakan metode tanya jawab pada anak tentang rumah 
e. Guru membagi anak menjadi tiga kelompok dan masingmasing kelompok diberi tugas yang berbeda.

f. Guru menjelaskan kegiatan yang akan dilakukan pada anak yaitu meronce dengan media manik-manik.

g. Guru menunjukkan alat yang akan digunakan dalam kegiatan meronce dengan manik-manik dan memperlihatkan media yang telah dibuat guru pada kelompok anak yang menjadi target perbaikan dan meyuruh anak mengerjakannya.

h. Anak-anak mengerjakan meronce dengan menggunakan manik-manik pada lembar kerja yang telah disediakan guru.

Berdasarkan hasil observasi yang dilakukan oleh peneliti dan kolaborator, ditemukan hal- hal yang terjadi selama pembelajaran perbaikan yaitu: Kegiatan pembelajaran berlangsung seperti yang diharapkan. Ada beberapa anak yang mampu mengerjakan kegiatan meronce dengan menggunakan manik-manik dengan sangat baik dan ada juga beberapa anak yang belum berkembang kemampuan motorik halusnya. Hal ini terlihat anak tidak dapat meronce dengan manik-manik sesuai dengan yang diperintahkan guru.

Kegiatan pembelajaran telah sesuai dengan indikator dan tingkat perkembangan anak, namun ada beberapa kegiatan yang harus dikembangkan dengan berbagai metode pembelajaran untuk memotivasi anak dalam melakukan kegiatan. Media pembelajaran yang dibuat guru dapat menimbulkan rasa keingintahuan yang besar pada anak, dan alat penilaian yang digunakan dapat mengukur perkembangan motorik halus anak. Sedangkan refleksi proses pengembangan pembelajaran telah sesuai dengan RPPH yang disusun sebagai pedoman pelaksanaan kegiatan.

Kekuatan dalam merancang dan melaksanakan kegiatan pengembangan pembelajaran telah sesuai dengan tingkat perkembangan kemampuan motorik halus anak dimana pelaksanaannya mengikuti skenario perbaikan pembelajaran yang telah disusun. Pelaksanaan kegiatan telah sesuai dengan RPPH kegiatan meronce denagan media manik-manik yang selama ini jarang dilakukan guru karena merepotkan dan membutuhkan perhatian. Sedangkan kegiatan meronce dengan media manik-manik ini dapat melatih konsentrasi dan motorik halus anak.

Dengan menggunakan media yang baru setiap hari membuat anak asyik dengan kegiatannya meronce dengan menggunakan media manikmanik. Namun dalam siklus I ini masih banyak kekurangannya antara lain: Beberapa anak tidak mau mengerjakan kegiatan meronce dengan menggunakan manik-manik yang dibuat guru karna anak belum memahami cara melakukan kegiatan dan masih belum paham apa yang harus dilakukan. Media yang dibuat 
guru kurang menarik karena hanya menggunakan satu macam manik saja disamping itu guru tidak memberikan reward terhadap hasil karya anak sehingga hasil yang diharapkan belum sesuai dengan harapan. Maka penelitian ini perlu dilanjutkan ke siklus berikutnya, untuk melakukan perbaikan.
Adapun tindakan perbaikan yang akan dilakukan peneliti pada siklus berikutnya selain mempertimbangkan keberhasilan dan kegagalan dalam proses kegiatan juga berdasarkan analisis hasil penilaian kegiatan pembelajaran yang dilakukan anak seperti tercantum pada tabel berikut:

Tabel Pencapaian Kemampuan Motorik Halus Anak Pada Siklus I

\begin{tabular}{|c|c|c|c|c|c|c|c|c|}
\hline \multirow[t]{2}{*}{ No } & \multirow[t]{2}{*}{ Indikator } & \multicolumn{5}{|c|}{ Hasil Pengamatan } & \multirow{2}{*}{$\begin{array}{c}\text { Rata- } \\
\text { rata }\end{array}$} & \multirow{2}{*}{$\%$} \\
\hline & & BSB & $\mathrm{BSH}$ & $\mathrm{MB}$ & $\mathrm{BB}$ & JLH & & \\
\hline 1. & $\begin{array}{l}\text { Keterampilan } \\
\text { menggunakan jari } \\
\text { jemari }\end{array}$ & - & 7 & 4 & 4 & 33 & 2.2 & $46 \%$ \\
\hline 2. & $\begin{array}{l}\text { Bereksplorasi } \\
\text { dengan berbagai } \\
\text { media }\end{array}$ & - & 6 & 6 & 3 & 33 & 2,2 & $40 \%$ \\
\hline 3. & $\begin{array}{l}\text { Koordinasi tangan } \\
\text { dengan mata }\end{array}$ & - & 8 & 5 & 3 & 36 & 2.4 & $53 \%$ \\
\hline 4. & Ketelitian anak dalam bekerja & - & 5 & 8 & 2 & 33 & 2.2 & $53 \%$ \\
\hline & Jumlah rata-rata & & & & & & 2.2 & $43 \%$ \\
\hline
\end{tabular}

Setelah peneliti merefleksi hasil kegiatan siklus I, maka didapatkan hasil sebagai berikut:

Dari 15 orang jumlah siswa yang terlibat dalam penelitian hanya 5-7 berkembang sesuai harapan, 4-8 orang yang mulai berkembang, dan 2-4 orang yang belum berkembang dari indikator pencapaian perkembangan dan belum ada yang berkembang sangat baik maka perlu dilanjutkan ke siklus II.

Berdasarkan hasil refleksi, peneliti memutuskan untuk mengadakan perbaikan karena hasil kemampuan perkembangan motorik halus anak pada siklus pertama belum memenuhi target yang ditetapkan yaitu rata-rata 2,2 atau hanya sekitar $43 \%$. Adapun rencana perbaikan yang akan peneliti lakukan untuk siklus II adalah: Memberikan penjelasan sebelum memulai kegiatan pembelajaran dengan bahasa yang mudah dipahami anak dan mencontohkan pada anak bagaimana cara mengerjakan kegiatan meronce dengan media manik-manik supaya hasilnya baik dan menggunakan media pembelajaran yang lebih menarik dan menambah manikmanik yang berwarna warni di variasikan serta memberikan reward terhadap hasil karya anak. 


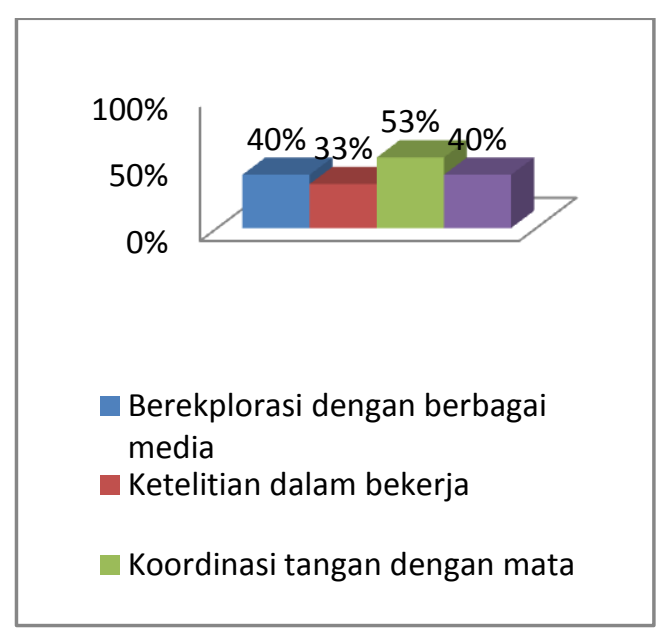

\section{Grafik pencapaian kemampuan} motorik halus anak pada siklus I

Menurut data dari penilaian grafik diatas terlihat bahwa kemampuan dalam keterampilan menggunakan jari jemari keberhasilannya hanya mencapai $46 \%$, bereksplorasi dengan berbagai media keberhasilannya $40 \%$, koordinasi tangan dengan mata keberhasilannya mencapai 53\%, dalam ketelitian anak dalam bekerja keberhasilannya hanya $33 \%$ serta dalam melatih otot-otot tangan dan jari keberhasilannya hanya $40 \%$. Jadi secara keseluruhan pelaksanaan perbaikan belum berhasil karena keberhasilan anak didik hanya mencapai $43 \%$.

Adapun data deskripsi hasil data tentang rencana, pelaksanaan, pengamatan dan refleksi pada tindakan siklus II adalah sebagai berikut :

Rencana perbaikan telah disusun berdasarkan akademis, sarana, prasarana dan fasilitas. Pengelolaan kelas sama seperti siklus I yaitu dengan model kelompok.

a. Guru melaksanakan kegiatan meronce dengan menggunakan manik-manik dengan memberikan dua macam manik seperti yang berwarna warni agar menarik perhatian anak.

b. Guru membuat skenario perbaikan pembelajaran yang telah ditetapkan sebagai hasil refleksi kegiatan siklus I.

Langkah-langkah yang dilakukan guru pada proses pembelajaran adalah sebagai berikut:

a. Guru tetap melakukan penenangan terhadap anak

b. Guru memberikan gambaran tempat yang akan ditanyakan

c. Guru melakukan tanya jawab pada anak tentang lingkungan rumahnya.

d. Guru membagi anak menjadi tiga kelompok dan masingmasing kelompok diberi tugas yang berbeda.

e. Guru memberikan penjelasan tentang cara melakukan kegiatan meronce dengan menggunakan manik-manik.

f. Guru menunjukkan media kegiatan meronce dengan menggunakan media manikmanik yang telah dibuat guru pada kelompok anak yang menjadi target perbaikan serta mencontohkan cara mengerjakannya.

g. Anak-anak mengerjakan kegiatan meronce dengan menggunakan manik-manik 
pada lembar kerja yang telah disediakan guru dan anak diperintahkan bebas berkreasi pada hasil karyanya.

h. Guru memberikan pujian pada anak yang telah berhasil mengerjakan dengan baik.

Berdasarkan hasil observasi yang dilakukan oleh peneliti dan teman kolaborator, ditemukan halhal yang terjadi selama perbaikan yaitu: Kegiatan pembelajaran berlangsung dengan tertib, dan hampir seluruh anak mampu mengerjakan kegiatan meronce dengan menggunakan manik-manik dengan sangat baik, terdapat 2 orang anak yang belum berkembang kemampuan motorik halusnya namun sudah ada kemajuan dari belum berkembang menjadi mulai berkembang. Hal ini terlihat anak cukup mampu mengkoordinasikan antara tangan dengan matanya. Terlihat beberapa anak meminta media lain untuk mengerjakan kegiatan meronce dengan menggunakan manik-manik lagi untuk membuat kreasi yang lain. Anak sudah bersemangat dan termotivasi dalam meronce dengan media manik-manik.

Dari hasi penelitian yang dilakukan maka dapat disimpulkan sebagai berkut: Kegiatan pembelajaran yang dilakukan telah sesuai dengan indikator dan tingkat perkembangan anak, namun ada beberapa kegiatan yang harus dikembangkan dengan berbagai metode pembelajaran untuk merangsang anak belajar. Media pembelajaran yang diberikan guru dapat menimbulkan rasa keingintahuan yang besar pada anak, dan alat penilaian yang digunakan dapat mengukur kemampuan perkembangan motorik halus anak. Refleksi proses pengembangan pembelajaran telah sesuai dengan RPPH yang disusun sebagai pedoman pelaksanaan kegiatan.

Kekuatan dalam merancang dan melaksanakan kegiatan pengembangan pembelajaran menunjukkan sudah sesuai dengan tingkat perkembangan kemampuan motorik halus anak dimana pelaksanaannya tetap mengikuti langkah-langkah perencanaan yang telah disusun. Pelaksanaan kegiatan telah sesuai dengan RPPH, dan media yang digunakan dalam kegiatan meronce dengan manikmanik telah ditambah guru dari satu jenis manik menjadi dua jenis manik yang berwarna warni sehingga menarik perhatian anak. Dengan media yang bervariasi membuat anak asyik melakukan kegiatannya meronce dengan manik-manik.

Secara umum kegiatan meronce dengan manik-anik berjalan sesuai harapan, namun ada 2 orang yang masih memerlukan bantuan guru untuk melakukan kegiatan meronce dengan menggunakan media manikmanik. Hal ini disebabkan karena kemampuan motorik halus anak baru mulai berkembang belum seperti anak yang lainnya.

Adapun hasil kerja anak-anak dapat dilihat pada analisis hasil penilaian 
siklus II kegiatan pembelajaran yang

pada tabel berikut:

dilakukan anak seperti tercantum

Tabel Pencapaian Kemampuan Motorik Halus Anak Pada Siklus II

\begin{tabular}{|c|c|c|c|c|c|c|c|c|}
\hline \multirow[t]{2}{*}{ No } & \multirow[t]{2}{*}{ Indikator } & \multicolumn{5}{|c|}{ Hasil Pengamatan } & \multirow{2}{*}{$\begin{array}{l}\text { Rata- } \\
\text { rata }\end{array}$} & \multirow{2}{*}{$\%$} \\
\hline & & BSB & BSH & MB & $\mathrm{BB}$ & JLH & & \\
\hline 1 & $\begin{array}{l}\text { Bereksplorasi dengan } \\
\text { berbagai media }\end{array}$ & 5 & 9 & 1 & - & 49 & 3.3 & $93 \%$ \\
\hline 2 & $\begin{array}{ll}\text { Koordinasi } & \text { tangan } \\
\text { dengan mata } & \end{array}$ & 9 & 4 & 2 & - & 52 & 3.5 & $87 \%$ \\
\hline 3 & Ketelitian anak dalam bekerja & 7 & 5 & 3 & - & 49 & 3.3 & $80 \%$ \\
\hline 4 & $\begin{array}{l}\text { Melatih otot-otot } \\
\text { tangan dan jari }\end{array}$ & 6 & 7 & 2 & - & 57 & 3.8 & $87 \%$ \\
\hline & Jumlah rata-rata & & & & & & 3.5 & $87 \%$ \\
\hline
\end{tabular}

Berdasarkan pada hasil observasi teman sejawat dan penilaian dari observer serta hasil refleksi dari keseluruhan proses dan analisis dari hasil belajar dan kegiatan anak maka rata-rata perkemangan motorik halus anak mencapai $88 \%$. Maka dapat diambil keputusan bahwa tidak perlu lagi dilakukan perbaikan lanjutan karena perbaikan pada siklus II telah memenuhi target atau telah berhasil yaitu sudah melebihi indikator kinerja yang ditentukan (70\%).

\section{Pembahasan}

Pada perbaikan siklus I ada beberapa temuan yang menjadi perhatian baik dari peneliti (guru), teman sejawat maupun supervisor sebagai penilai. Adapun temuan tersebut antara lain :
a. Kegiatan
pembelajaran
berlangsung dengan tertib dan

menyenangkan. Guru harus memiliki banyak metode dalam kegiatan pembelajaran sehingga anak menjadi asyik dan gembira. Hal tersebut membuat proses belajar tidak membosankan bagi anak.

b. Beberapa anak yang mampu mengerjakan kegiatan meronce dengan menggunakan media manik-manik sesuai harapan.

Hal ini disebabkan oleh perkembangan fisik motorik halus anak telah berkembang sebagai mana mestinya.

c. Ada juga beberapa anak yang belum berkembang kemampuan motorik halusnya. Hal ini terlihat anak tidak dapat melatih otot-otot tangan dan jarinya.

d. Hasil penilaian kegiatan anak keseluruhan : 
Erna Kusnita : Meningkatkan Kemampuan ....

Tabel Persentase Pencapaian Kemampuan Motorik Halus Anak Pada Siklus I

\begin{tabular}{|c|c|c|c|c|c|}
\hline \multirow[b]{2}{*}{ No } & \multirow[b]{2}{*}{ Aspek yang dinilai } & \multicolumn{4}{|c|}{ Jumlah anak } \\
\hline & & BSB & BSH & MB & BB \\
\hline \multirow[t]{2}{*}{1} & Bereksplorasi dengan berbagai media & - & 6 & 6 & 3 \\
\hline & Persentase & - & $40 \%$ & $40 \%$ & $20 \%$ \\
\hline \multirow[t]{2}{*}{2} & Koordinasi tangan dengan mata & - & 8 & 5 & 2 \\
\hline & Persentase & - & $53 \%$ & $33 \%$ & $14 \%$ \\
\hline \multirow[t]{2}{*}{3} & Ketelitian anak dalam bekerja & - & 5 & 8 & 2 \\
\hline & Persentase & - & $33 \%$ & $53 \%$ & $14 \%$ \\
\hline \multirow[t]{2}{*}{4} & Melatih otot-otot tangan dan jari & - & 6 & 5 & 4 \\
\hline & Persentase & - & $40 \%$ & $33 \%$ & $27 \%$ \\
\hline
\end{tabular}

\section{Keterangan Nilai :}

BB : Belum Berkembang

MB : Mulai Berkembang

BSH : Berkembang Sesuai Harapan

BSB : Berkembang Sangat Baik

Pada perbaikan siklus II ada beberapa temuan yang menjadi perhatian baik dari peneliti (guru), teman sejawat maupun supervisor sebagai penilai. Adapun temuan tersebut antara lain :

a. Kegiatan pembelajaran berlangsung dengan tertib dan menyenangkan.

Hal ini dapat tercapai karena usaha guru memberikan motivasi dan menyediakan media pembelajaran yang menarik minat anak sehingga anak yang tidak mau mengerjakan kegiatan meronce dengan menggunakan manik-manik menjadi mau mengerjakannya.

b. Hampir seluruh anak mampu mengerjakan kegiatan meronce dengan menggunakan media manik-manik dengan sangat baik.
Hal ini terjadi karena media yang digunakan anak menarik dan berwarna warni sehingga anak asyik mengerjakannya.

c. Ada 2 orang anak yang belum berkembang kemampuan motorik halusnya namun sudah ada kemajuan dari belum berkembang menjadi mulai berkembang. Hal ini terlihat anak cukup mampu menggerakkan jari-jemarinya dengan lentur.

d. Beberapa anak meminta kertas untuk mengerjakan kegiatan meronce dengan menggunakan manik-manik lagi membuat kreasi yang lain.

Hal ini terjadi karena anak sangat menikmati/ bangga akan hasil karyanya sehingga anak ingin menunjukkan keahliannya dengan membuat karya yang lain lagi dan lagi. 
Tabel Persentase Pencapaian Kemampuan Motorik Halus Anak Pada Siklus II

\begin{tabular}{|c|l|c|c|c|c|}
\hline \multirow{2}{*}{ No } & \multicolumn{2}{|c|}{ Aspek yang dinilai } & \multicolumn{3}{c|}{ Jumlah anak } \\
\cline { 3 - 6 } & & BSB & BSH & MB & BB \\
\hline \multirow{2}{*}{1} & Bereksplorasi dengan berbagai media & $\mathbf{5}$ & 9 & 1 & - \\
\cline { 2 - 6 } & Persentase & $6 \%$ & $87 \%$ & $1 \%$ & - \\
\hline \multirow{2}{*}{2} & Koordinasi tangan dengan mata & $\mathbf{9}$ & 4 & 2 & - \\
\cline { 2 - 6 } & Persentase & $60 \%$ & $27 \%$ & $13 \%$ & - \\
\hline \multirow{2}{*}{} & Ketelitian anak dalam bekerja & $\mathbf{7}$ & 5 & 3 & - \\
\cline { 2 - 6 } & Persentase & $47 \%$ & $33 \%$ & $20 \%$ & - \\
\hline \multirow{2}{*}{} & Melatih otot-otot tangan dan jari & 6 & 7 & 2 & - \\
\cline { 2 - 6 } & Persentase & $40 \%$ & $47 \%$ & $13 \%$ & - \\
\hline
\end{tabular}

\section{Keterangan Nilai :}

BB : Belum Berkembang

MB : Mulai Berkembang

BSH : Berkembang Sesuai Harapan

BSB : Berkembang Sangat Baik

\section{Pembahasan}

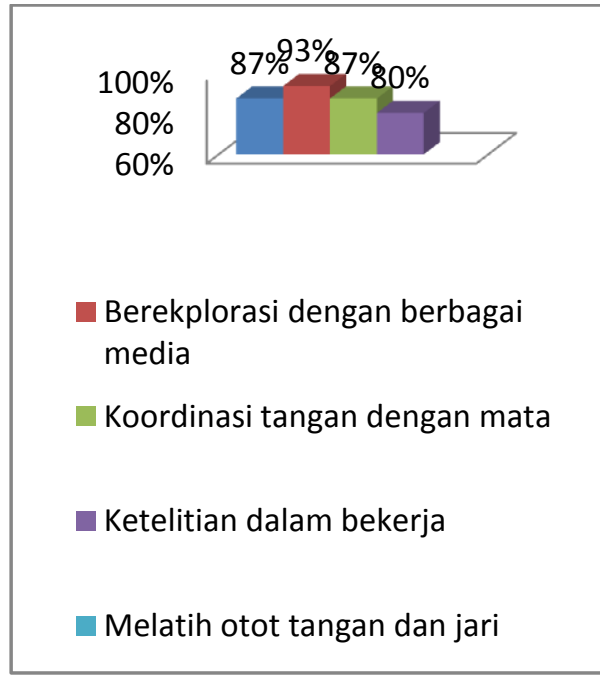

\section{Grafik Capaian perkembangan fisik} motorik halus anak pada Siklus II

Berdasarkan data dari penilaian grafik diatas terlihat bahwa kemampuan dalam keterampilan menggunakan jari jemari dengan kriteria Berkembang Sesuai Harapan dan Berkembang Sangat Baik keberhasilannya telah mencapai $87 \%$, bereksplorasi dengan berbagai media keberhasilannya 93\%, koordinasi tangan dengan mata keberhasilannya mencapai $87 \%$, dalam Ketelitian anak dalam bekerja keberhasilannya $80 \%$, serta dalam Melatih otot-otot tangan dan jari keberhasilannya telah mencapai $87 \%$. Jadi secara keseluruhan pelaksanaan perbaikan pada siklus II telah berhasil dengan perolehan keberhasilan anak didik mencapai $88 \%$.

Hal ini terbukti dari hasil tahapan siklus yang memperlihatkan bahwa Pencapaian kemampuan motorik halus anak setelah 
diterapkan kegiatan meronce dengan menggunakan manik-manik di TK Aisyiyah Bustanul Athfal Bromo Medan mengalami perkembangan rata-rata pada siklus I adalah $43 \%$, dan pada siklus II adalah $88 \%$ yang dapat dilihat dari gambar 9 dibawah ini:

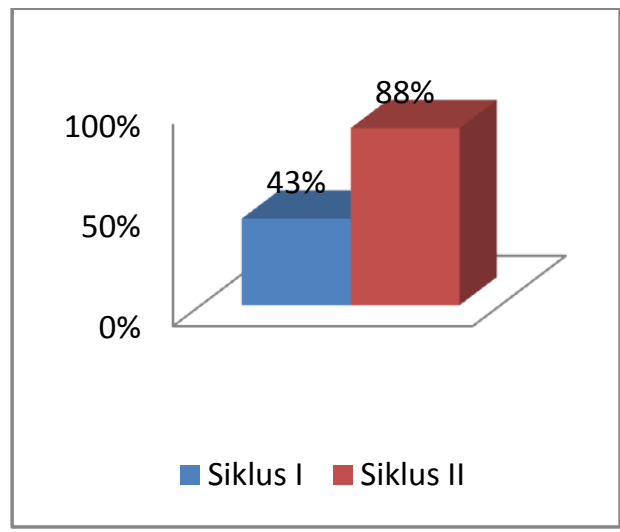

Grafik Pencapaian kemampuan motorik halus anak setelah diterapkan kegiatan meronce dengan menggunakan media manik-manik di TK Aisyiyah Bustanul Athfal Bromo Medan pada Siklus I dan Siklus II

\section{SIMPULAN}

Berdasarkan hasil penelitian dalam pembahasan tentang upaya meningkatkan perkembangan kemampuan fisik motorik halus anak usia dini melalui kegiatan meronce dengan menggunakan manik-manik di TK Aisyiah Bustanul Atfal Bromo Medan dapat disimpulkan bahwa :

a. Perkembangan fisik motorik halus anak di TK Aisyah Bustanul Atfal Bromo Medan sebelum diterapkan kegiatan meronce dengan menggunakan media manik-manik masih belum optimal kematangannya. Hal ini dapat terlihat dari capaian perkembangan anak dalam keterampilan menggunakan jari jemari, bereksplorasi dengan berbagai media, koordinasi tangan dengan mata, ketelitian dalam bekerja serta dalam melatih otot-otot jari dan tangan masih dibawah rata rata yang diharapkan yaitu rata-rata 2, sedangkan rata rata yang diharapkan dapat dicapai anak yaitu rata-rata 3 .

b. Penerapan kegiatan meronce dengan menggunakan manikmanik di TK Aisyah Bustanul Atfal Bromo Medan untuk meningkatkan perkembangan fisik motorik halus anak usia dini dapat berjalan sesuai perencanaan dan sangat efektif. Hal ini dapat dilihat dari kemampuan anak pada siklus I yang mencapai $43 \%$ dan pada siklus II yang mencapai $88 \%$. Artinya tingkat perkembangan fisik motorik halus anak mengalami kemajuan.

c. Adapun cara meningkatkan perkembangan fisik motorik halus anak usia dini di TK Aisyah Bustanul Atfal Bromo Medan dengan optimal seperti yang diharapkan yang dilakukan peneliti yaitu dengan menerapkan kegiatan meronce dengan menggunakan media manikmanik. 
DAFTAR RUJUKAN

Aisyah, Siti, dkk. 2012. Perkembangan dan Konsep Dasar Pengembangan Anak Usia Dini. Universitas Terbuka. Gunarti, Winda, dkk. 2012. Metode Pengembangan Perilaku dan Kemampuan Dasar Anak Usia Dini, Universitas Terbuka.

Hurlock B., Elizabeth. 2008. Perkembangan Anak (jilid 1), Jakarta: Erlangga.
May Lwin, dkk. 2005. Cara Mengembangkan Berbagai Komponen Kecerdasan. Jakarta. Moleong,. 2003. Metode Penelitian Kualitatif, Bandung: Erlangga Musfiroh, Tadkiroatun. 2012. Pengembangan Kecerdasan Majemuk, UniversitasTerbuka Undang-undang Republik Indonesia No. 20 tahun 2003 Tentang Sistem Pendidikan Nasional. 